一論 文一
（日本化学会誌，1990，（2), p.185 191)

(C) 1990 The Chemical Society of Japan

\title{
動的光散乱法を用いたオボトランスフェリンの ランタノイドイオンの結合にともなう形態変化
}

\author{
（1989 年 6 月 26 日受理）
}

\author{
佐々木範之・本田恒・矢島博文・百海浩行 \\ 市村董・佐竹一夫**遠藤隆一*
}

\begin{abstract}
ニワトリ卵白由来のオボトランスフェリン (OTf) は，分子のアミノ末端側 $(\mathrm{N})$ ，カルボキシル末端 側（C）にそれぞれ金属結合部位を一つずつもつ。これら金属結合サイトの金属錯体の性質として, 一 連のランタノイド $(\operatorname{Ln}(\mathrm{III}))$ イオンを用いた研究によって，結合する金属のイオン半径に錯体の安定性 が大きく依存し，イオン半径の減少により錯体の安定性が增加することが示され，しかも， $\operatorname{Ln}($ III) イオンはN結合サイトよりもC結合サイトに結合しやすいことも山村らにより示された。本研究では, OTf が $\operatorname{Ln}($ III) イオンの結合にともなら分子の形態変化を, 拡散㐿数を指標にして, 系統的に比較 検討した。一連の OTf $\cdot \operatorname{Ln}($ III ) 錯体の拡散係数の変化は原子番号の増加とともに增加し，その傾向は， $\operatorname{Ln}($ III) のイオン半径の減少によい相関関係を示した。分子の形態变化（护そらく収縮）は， Ln(III) のイオン半径の減少に依存することが示唆された。OTf・Ln(III) 錯体の安定性は, $\operatorname{Ln}($ III) タオンの結 合にともなう OTf・Ln(III) 錯体の分子の形態変化と関係があることが推測される。また，OTf に対し て金属イオンを徐々に添加していった時の拡散係数の变化は, 実験を行ったすべての $\operatorname{Ln}($ III) 錯体で, 金属イオンの添加量そのものよりる，金属添加時に生成したC 結合サイト錯体量に，より密接に関係し た挙動を示した。また, $\operatorname{Ln}($ III) 結合にともなら拡散係数の変化をより明確にするために，N結合サイ トに比較的結合しやすい $\mathrm{Cu}(\mathrm{II})$ イオンを用いて，それを比較したところ，拡散係数の变化は， C結合 サイト金属錯体の生成量とよい相関関係が認められた。このことから，金属イオンの結合にともなら形 態変化が，N結合サイトよりC結合サイトの方がより大きいと示唆された。
\end{abstract}

\section{1 緒言}

鳥類卵白中に存在するオボトランスフェリン（以下 OTf と略 記する) は, 脊椎動物血清中に存在する血清トランスフェリン (以下 STf と略記する) や乳汁由来のラクトフェリンとともに一 群の金属結合性タンパク質トランスフェリンの superfamily を形 成する12)。特にニワトリ卵白由来の OTf は一群のトランスフェ リン（以下 Tf と略記する）のモデル物質として研究されてきた。 Tf 分子は, 分子量約 80000 のグリコシル化された 1 本のポリペ プチド鎖から構成され，ポリペプチドのほぼ中央部分から，アミ ノ末端側 $(\mathrm{N})$ 半分とカルボキシル末端側 (C) 半分がそれぞれ コンパクトに折りたたまれた，二つの独立した領域（ドメイン） を形成している。また， N， C 両ドメインは一次棈造上非常に高 い相同性を示し，X線結晶解析の結果によると，高次構造上で互

東京理科大学理学部応用化学科, 162 東京都新宿区神楽坂 ** 東京理科大学理学部化学科, 162 東京都新宿区神楽坂

1) M.-H. Metz-Boutigue, J. Jolles, J. Mazurier, F. Schoentgen, D. Legrand, G. Spik, J. Montreuil, P. Jolles, Eur. J. Biochem., 145, 659(1984).

2) J.H. Brock, "Topics in Moleculare and Structural Biology", Ed. by P. Harrison, Verlag Chemie, Weinheim, Basel, Vol.7, p. 187(1985).
いに類似した半球状を示す ${ }^{8 / 4)}$ この N，C ドメインには，それ ぞれ一つずつ金属結合部位（NサイトおよびCサイト）をあち, 金属イオンを結合する配位子は両サイトとも等しいことが一次 構造上の相同性やX線結晶解析などの研究から明らかにされ

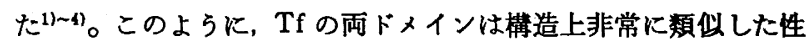
質をむつが，必ずしも等価でなく，両ドメイン間の機能の相違を

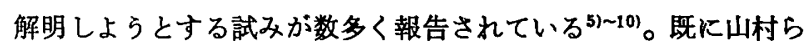

3) B. Gorinsky, C. Harsburgh, P. F. Lindley, D. S. Moss, M. Markerand, J. L. Watoson, Nature, 287, 157(1979).

4) H. M. Baker, E. J. Dodson, G. E. Norris, S. V. Rumball, J. M. Wates, E. N. Baker, Proc. Natul. Acad. Sci. U.S. A., 84, 1769(1987).

5) J.Williams, R. W. Evans, K. Moreton, Biochem. J., 173, 535(1987).

6) D. C. Harris, Biochemistry, 16, 560(1977).

7) E. H. Morgan, Biochim. Biophys. Acta, 580, 312(1979).

8) T. Yamamura, H. Ikeda, K. Nakazato, M. Takimura, K. Satake, "Proteins of Iron Strage and Transport", Eds. by G.Spik, J. Montreuil, R. R. Chichton, J. Mazurier, Elsevier Science Pub., Amusterdam (1985) p. 53.

9) T. Yamamura, S. Hagiwara, K. Nakazato, K. Satake, Biochem. Biophys. Res. Commun., 119, 298(1984). 
は, ニワトリ由来の OTf ととト由来の STf の N, C 両サイト の錯形成能と安定性の相違を明確にするために，化学的に性質の 類似した一連のランタノイド金属イオン（以下 $\operatorname{Ln}($ III) と略記す る）をプローブとして，括もに Tf・Ln(III)錯体の EDTA による 錯体崩壊の速度定数を湘定し, $\mathrm{Tf} \cdot \operatorname{Ln}($ III) 錯体に関して $\operatorname{Ln}($ III) $・$ Cサイト錯体の方が $\operatorname{Ln}(\mathrm{III}) \cdot \mathrm{N}$ 錯体よりも安定性が高いこと,

それぞれのサイトでの $\ln ($ III) 錯体の安定性は $\operatorname{Ln}($ III) のイオン 半经が小さくなるほど，相対的に錯体の安定性が高くなることを 示した ${ }^{10)}$ 。さらに OTf においては, ある一定量の金属イオンを 添加すると両サイトに等しく結合せず，ほとんどの金属イオン 種がどちらか一方のサイトに，より優先的に結合することが知 られている(0)11)。Nサイト占有性をるつるのとしては $\mathrm{Fe}(\mathrm{III})$, $\mathrm{Cu}$ (II)， $\mathrm{Al}$ (III) など'1)， Cサイト占有性をるつものとしては Y(III) をはじめ, $\operatorname{Pr}($ III $), \operatorname{Nd}($ III $), \operatorname{Sm}($ III), $\operatorname{Eu}($ III), $\operatorname{Gd}($ III), $\mathrm{Tb}($ III $), \mathrm{Dy}($ III), $\mathrm{Ho}($ III), $\operatorname{Er}($ III), $\mathrm{Yb}($ III) が報告されてい $3^{10)}$ 。

一方，X線小角散乱の研究から，Tf は $\mathrm{Fe}$ (III)イオンを結合す ると金属を結合しない状態にくらべ，分子の回転半径が小さくな ることが示されている(2)18)。

本研究では，金属イオンが結合することで分子の形態が变化 する挙動を, 形態変化の一つの指標として払散係数（以下 $D$ と する）を測定することにより検討した。そして金属イオンとし て $\mathrm{Cu}$ (II) および化学的性質が類似しイオン半径のみが異なる $\operatorname{Ln}$ (III) を用いて，形態変化のもたらす主要因を明確にする。

\section{2 実験}

2.1 試 料

ニワトリ OTf は，新鮮なニワトリ卵白から，山村らの方法" に したがって精製したすのを使用した。

$\operatorname{Ln}($ III) 金属塩は, $\mathrm{Nd}(\mathrm{III}), \mathrm{Sm}(\mathrm{III}), \mathrm{Eu}(\mathrm{III}), \mathrm{Gd}(\mathrm{III})$, $\mathrm{Tb}($ III $), \mathrm{Dy}(\mathrm{III}), \mathrm{Ho}$ (III), $\operatorname{Er}($ III), $\mathrm{Yb}($ III) 塩化物塩で Aldrich 社のすのを使用した。そのほか使用したすべての試薬は，試薬特 級のものをそのまま使用した。

\section{2 試料溶液の調製}

apoOTf を $10 \mathrm{mmol} \cdot \mathrm{dm}^{-3} \mathrm{NaHCO}_{3}$ を含む $10 \mathrm{mmol} \cdot \mathrm{dm}^{-8}$ Tris(hydroxymethyl)aminomethane（以下 Tris と略記する)$\mathrm{HCl}$ 衝液, $\mathrm{pH} 8.0$ に溶解し，その濃度は $E_{280 \mathrm{~nm}}^{1 \%}=11.3^{14)}$ お よび分子量 7777015)を用いて決定した。

各種 $\operatorname{Ln}(\mathrm{III})$ 錯体は，一定量の金属イオン溶液を，濃度の決定 した apoOTf にできるたけ均一になるように添加し，調製した。 調製した各種 OTf 金属錯体溶液は，光散乱測定を行う前に，

10）山村堯樹, 市村 蒸, 津田 透, 林 敦子, 谷口高広, 戸 井利香子，前田芳人，木原 裕，佐竹一夫，日化，1988， 452.

11) T. Yamamura, S. Shimo, T. Tsuda, K. Satake, Rep. Prog. Polym. Phys. Jpn., 28, 633(1985).

12) T. Yamamura, K. Ichimura, K. Satake, Y.Tachi-iri, H. Kihara, Y. Amemiya, Photon Factry Activity Peport, 4, 308(1986).

13) L. Kilar, I. Simon, Biophys. J., 48, 799(1985).

14) A.N. Glazer, H. A. McKenzie, Biochim. Biophys. Acta, 71, 109(1963).

15) J. Williams, T. C. Elleman, B. Kingston, A. G. Wilkins, K. A. Kuhn, Eur. J. Biochem., 122, 297(1982).
セルロースアセテート メンブランフィルター（0.22 $\mu \mathrm{m}, \mathrm{Mil}$ lipore LTD. 製) を $2 \sim 3$ 回通した後，測定に使用した。

$2.3 \mathrm{Cu}(\mathrm{II})$ 錯体の調製

山村らによれば $\mathrm{Cu}$ (II)イオンは, $\mathrm{pH} 8$ 付近では $\mathrm{N}$ サイトに選 択的に結合する819)。OTf・Cu(II) のらちでNサイトに優先的に配 向させた錯体（以下 $\mathrm{OTf}(\mathrm{N}) \cdot \mathrm{Cu}(\mathrm{II})$ 錹体と示す）は，この方法 にしたがって調製した。

$\mathrm{Cu}$ (II) を強制的にCサイトに多く結合させた錯体（以下， $\mathrm{OTf}(\mathrm{C}) \cdot \mathrm{Cu}(\mathrm{II})$ 錯体と示し， Nサイトにより多く結合した錯体， $\mathrm{OTf}(\mathrm{N}) \cdot \mathrm{Cu}(\mathrm{II})$ と区別する）を Baldwin と deSousa の方法 ${ }^{18)}$ を参考にして調製した。すなわち，OTf 溶液を酸性下（約 $\mathrm{pH}$ 5.5) で $\mathrm{Cu}$ イオンを添加し，その後 $\mathrm{pH}$ を徐々に 8 にして調製 した。OTf のN怙よびCサイトに結合している量は山村らの報 告》にしたがって，EDTA による $\mathrm{Cu}$ の引き抜き反応速度と吸光 度から求めた。本実験では，まず約 $1 \%$ の OTf(C). $\mathrm{Cu}(\mathrm{II})$ を 調製し，その一部からN拉よびCサイト鍇体の形成量を EDTA 引き抜き法 ${ }^{819)} に よ り$ 調べ，残りの溶液はTris 緩衝液で希釈し て，光散乱測定に使用する溶液を調製した。

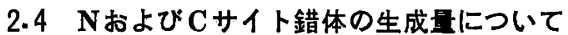

OTf の $\mathrm{N}, \mathrm{C}$ サイト選択性は， $\ln ($ III) では，ょり優先的に $\mathrm{C}$ サイトに, $\mathrm{Cu}($ II $)$ では，上り優先的にNサイトに結合するこ とが示された ${ }^{910)}$ 。そして，金属イオンをOTf に添加したとき， OTf の N, C 二つの結合サイトに結合した分配比は, EDTA に よる金属の引き抜き反応から決定した ${ }^{10111) 。 ~}$

一方，OTf の金属錯体の生成の仕方は，下の図式の様になる (詳細は引用文献 8)，17）を参照)。

EDTA による N， C 金属錯体の崩复速度が異なる（二相性） こと, $t=0$ に招ける各相の吸光度比がN怙よびCサイト錯体生成 量の比に比例することから，各サイトの錯体生成量を計算するこ とができる ${ }^{10111)}$ 。モデル解析に用いた飽和度 $(\theta)$ と， N， C サ イト結合比 $(y)$ の関係式は, $\theta=[\mathrm{N}]+[\mathrm{C}], y=[\mathrm{C}] /[\mathrm{N}]$ で 示される。これから，N拉よびCサイト錯体の相対的な生成量は 次式で表すことができる。

$$
[\mathrm{N}]=\frac{\theta}{y+1}
$$

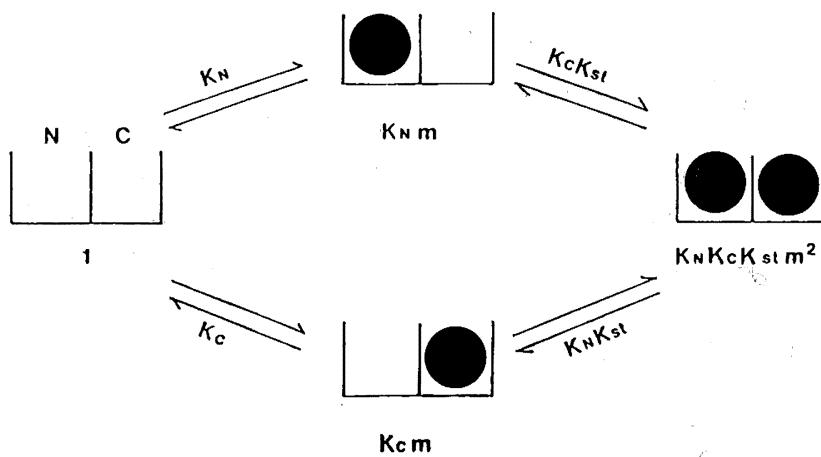

Scheme

16) D. A.Baldwin, D. M. R. deSousa, Biochem. Biophys. Res. Commun., 99, 1101(1987).

17) K. Ichimura, H. Kihara, T. Yamamura, K. Satake, $J$. Biochem., 106, 50(1989). 


$$
[\mathrm{C}]=\frac{\theta y}{y+1}
$$

一方，上の図式中で，

$$
\begin{aligned}
& Q=1+K_{\mathrm{N}} m+K_{\mathrm{O}} m+K_{\mathrm{N}} K_{\mathrm{C}} K_{\mathrm{st}} m^{2} \\
& \theta=\left(K_{\mathrm{N}} m+K_{\mathrm{O}} m+2 K_{\mathrm{N}} K_{\mathrm{O}} K_{\mathrm{Bt}} m^{2}\right) /(2 Q) \\
& y=\left(K_{\mathrm{O}} m+K_{\mathrm{N}} K_{\mathrm{O}} K_{\mathrm{st}} m^{2}\right) /\left(K_{\mathrm{N}} m+K_{\mathrm{N}} K_{\mathrm{O}} K_{\mathrm{st}} m^{2}\right)
\end{aligned}
$$

式（3）から（5）を整理し，K $K_{\mathrm{Bt}}=1$ (協同効果がない場合）を 代入すると

$$
y-2 \theta+1=\lambda(1 / y-2 \theta+1)
$$

が得られる。な拉， $\lambda=K_{\mathrm{O}} / K_{\mathrm{N}}$ ，とおく。この式を分配比 $y$ につい て解くと,

$$
y=(\lambda-1)(1-2 \theta)+\sqrt{((\lambda-1)(1-2 \theta))^{2}+4 \lambda}
$$

となる。分配比 $y$ は，入が与えられれば， $\theta$ のみの関数となる。 この $y$ を用いて，式 (1)，（2）から，各飽和度における N結合 サイト， C 結合サイト錯体の生成量の割合をシミュレートした。 なお， $\mathrm{Tb}(\mathrm{III})$ および $\mathrm{Cu}(\mathrm{II})$ が OTf に結合する時には， N，C サイト間には協同性がない田17いうことが佐竹らによって報告 されている。また， Tb(III), $\mathrm{Cu}(\mathrm{II})$ の OTf のN結合サイトに 対する $\mathrm{C}$ 結合サイトの平衡定数比 $\lambda$ は, $\lambda\left(=K_{\mathrm{C}} / K_{\mathrm{N}}\right)=2.2 \pm$ $0.2\left(\mathrm{~Tb}\right.$ (III) の場合) ${ }^{17)}$ および $0.25 \pm 0.2$ ( $\mathrm{Cu}\left(\right.$ III) の場合) ${ }^{8)}$ を用いた。各飽和度における金属イオンの $\mathrm{N}, \mathrm{C}$ サイトの錯体生 成量の計算値と, 実験で得られた錯体の生成量の割合を比較し た。実験に使用した OTf の濃度範囲では， $\theta, \lambda$ の濃度依存性は 認められなかった。

\section{$2.50 T f$ 金属錯体の拡散係数の測定}

各 OTf 金属錯体溶液に対する動的光散乱測定は大塚電子社製 の DLS-700 (光源 $\mathrm{Ar}^{+}$レーザー, $488 \mathrm{~nm}$ ) を用いて行った。こ

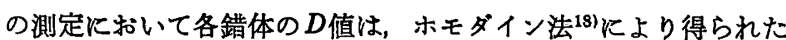
散乱光の自己相関関数曲線をキュムラント法 ${ }^{19)}$ に基づき解析し 決定した。測定散乱角度は $35^{\circ}$ ，温度は $25 \pm 0.2^{\circ} \mathrm{C}$ で行った。な お，測定した $D$ 值の誤差はおおおむね $\pm 0.06 \%$ であった。

\section{3 結果および考察}

\section{1 各種 OTf·Ln(III) 錯体の形成と拡散係数}

$\mathrm{Tf} \cdot \operatorname{Ln}(\mathrm{III})$ 鍇体は可視部に吸収をるたない無色錯体である。乙 かしながら，金属結合部位の配位子群の中にチロシン残基が存在 するため，この残基のフェノール性のヒドロキシル基のブロトン が金属結合時に金属イオンに固換されることにより，芳香族環の 吸収スペクトルに変化が生ずるので金属が結合したことがわか る。OTf $\cdot \operatorname{Ln}($ III)錯体 vs. apoOTf の差吸収スペクトルでは特徵 的なピーク $(245,290 \mathrm{~nm}$ 近辺) が出現し，この吸光度の変化を モニターすることで OTf $\cdot \operatorname{Ln}(\mathrm{II})$ 錯体の生成量を知ることができ $3^{1011120)}$ 。四 1 (A) に OTf の Ln(III)イオンによる滴定の一例 として $\mathrm{Tb}$ (III)イオンの場合を示す。 $\mathrm{Tb}(\mathrm{III})$ イオンは $[\mathrm{Tb}(\mathrm{III})]$ !

18) T. A. King, M. F. Treadaway, J. Chem. Soc., Farady Trans 2, 73, 1616(1977).

19) D. E. Koppel, J. Chem. Phys., 57, 4814(1972).

20) A.T. Tan, R. C. Woodworth, Biochemistry, 8, 3711 (1969).
[OTf]～2.1 で完全に飽和した。これは OTf に存在する二つの 金属結合部位に $\mathrm{Tb}$ (III)イオンが完全に結合したことを示す。な お，今回使用したすべての他の $\ln ($ III)イオンについても同様な 滴定曲線が得られた（Data not shown)。一方, Tb(II)イオンを 徐々に飽和させた時の $D$ 值の変化を図 1 (B) に示す。 $[\mathrm{Tb}(\mathrm{III})] /$ [OTf]〜2.2 まで，添加した $\mathrm{Tb}(\mathrm{III})$ イオンの増加ととるに，D 值も増加した。またこの比以上, $\mathrm{Tb}$ (III)イオンを添加してもD值 のいらじるしい変化は認められなかった。遊離の $\ln ($ III)イオン の影響はあまりないと推測できた。また，金属添加した時の各 $\mathrm{OTf}-\mathrm{Tb}$ 溶液の $D$ 值の角度依存性は串験誤差内（土2\%）でほと んど認められなかった。 $\ln ($ III ) の添加量を変化させたときのD 值は，今回実験を行った他のすべての $\ln ($ III) 錯体についても同 様な変化を示し，さらに金属滴定曲線の吸光度変化と $D$ 值の变化 がほぼ対応していることが認められた。金属滴定によるD值の変 化を他の $\operatorname{Ln}(\mathrm{III})$ 金属イオンについて, 図 2 (A)〜 (D) に示し た。

\section{2 飽和 OTf $\cdot \operatorname{Ln}(\mathrm{III})$ 錯体の㹡散係数 と $\operatorname{Ln}(\mathrm{III})$ イオン半 径の関係}

因 3 に示したよらに一連の飽和 OTf $\cdot \operatorname{Ln}($ III) 錯体の $D$ 值と $\ln \left(\right.$ III) イオンのイオン半径 ${ }^{21}$ ) との間にはイオン半径の増大 (原子 番号の減少) とともにD值が減少するといら明瞭な関保が認めら れた。OTf の金属結合にともなら形態変化は, 結合する金属イオ ンの大きさに依存することが示唆された。一方，山村らは，イオ ン半径が小さい㾏ど $\ln ($ III)錯体の安定性が高いといらことを示 した10)。そして，EDTA による $\operatorname{Ln}($ III)イオン引き抜きの反応速

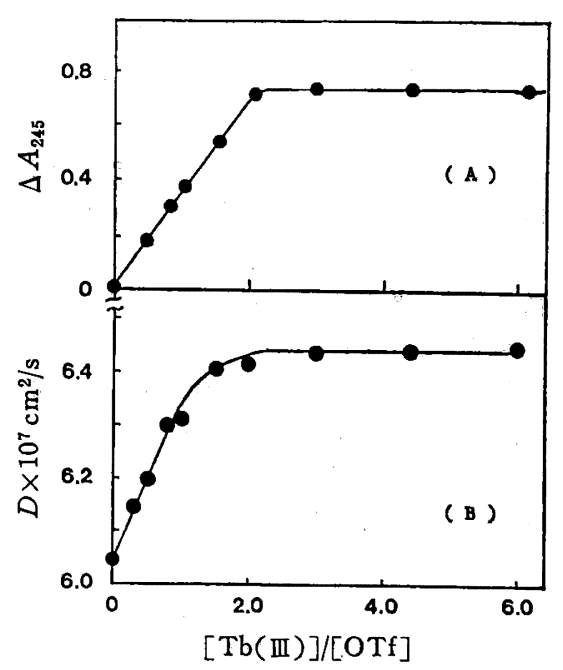

Fig. 1 Absorbance at $245 \mathrm{~nm}$ (A) and diffusion coefficient (B) of the $\mathrm{Tb}(\mathrm{II})$-OTf complex as a function of the molar ratio of $\mathrm{Tb}$ (III) to OTf

Conditions : $[\mathrm{OTf}]_{\mathrm{T}}=1.2 \times 10^{-5} \mathrm{~mol} \cdot \mathrm{dm}^{-3}(\mathrm{~A}), 4.5$ $\times 10^{-5} \mathrm{~mol} \cdot \mathrm{dm}^{-3}$ (B) in $10 \mathrm{mmol} \cdot \mathrm{dm}^{-3}$ Tris- $\mathrm{HCl}$ buffer containing $10 \mathrm{mmol} \cdot \mathrm{dm}^{-3} \mathrm{NaHCO}_{3}, \mathrm{pH} 8$; Temp. $25 \pm 0.2^{\circ} \mathrm{C}$

21）参考として，結晶イオン半径を用いた；N.E. Topp, "Chemistry of The Rere-Earth Elements", 㙁川二朗, 足立吟也訳, “希土類元素の化学”, 化学同人 (1974)p. 10. 

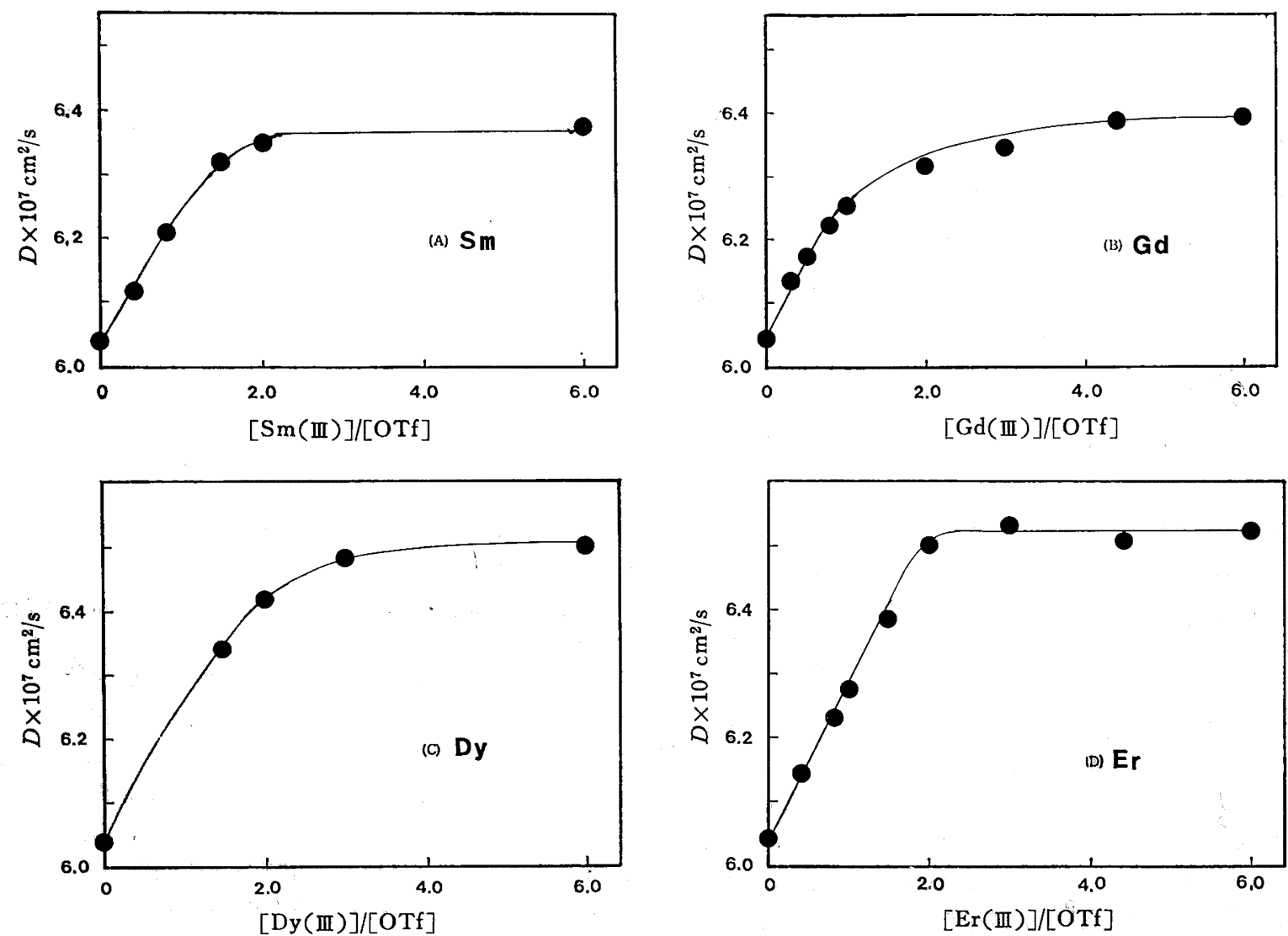

Fig. 2 Diffusion coefficients of the $\operatorname{Ln}(\mathrm{III})-\mathrm{OTf}$ complexes as a function of the molar ratio of the protein and metal ion

(A) $\mathrm{Sm}$ (III), (B) $\mathrm{Gd}($ III), (C) $\mathrm{Dy}$ (III), (D) $\operatorname{Er}$ (III)

Conditions : were the same as Fig. 1

度定数から，この安定性の原因が錯体形成部位の配位子と金属イ オンの相互作用の強さ，すなわち，解離定数の大ささによるもの と結論した。これらのことから，錯体の安定性の強さは，各種金 属イオンの結合にとるなう OTf 分子の形態変化と密接な相関関 係を示すこと肪示唆された。一方， X線小角散乱の結果 ${ }^{12) 13) か ら ~}$ 類推すれば; $D$ 值の変化は金属イオンの結合により起こる形態変 化に関連して, OTf $\cdot \operatorname{Ln}($ III) 錯体分子の見かけの半径の減少に関 係するものと予想される22)。

$3.30 T f \cdot \operatorname{Ln}(I I I) の N お よ ひ ゙ C$ 結合部位錯体の生成量と拡散 係数の変化

C 結合サイト選択性を示す $\mathrm{Tb}$ (III)イオンの添加により, 生成 する $\mathrm{OTf} \cdot \mathrm{Tb}$ (III) 錯体の $D$ 値の変化をより詳細にみると（図 1 参 照), $[\mathrm{Tb}(\mathrm{III})] /[\mathrm{OTf}] \sim 1.2$ までは，ほほ線的に増加し，これ 以降ほぼ 2.2 むでは緩やかな曲線を示す傾向が認められた。この 二相的な変化の挙動は, 添加した $\operatorname{Ln}(\mathrm{III})$ と OTf の比に多少の 違いはあるが，今回測定したすべての $\operatorname{Ln}($ III) について認められ

22） X線小角散乱の結果は， apoOTf; 的 $3.2 \AA$, OTf $\cdot \mathrm{Fe}_{2}$; 䄪 $3 \AA$ (Ref. 12) と報告されている. Stokes-Einstein の関係式 $d=k T / 6 \pi \eta_{0} D$ ) ( $D$ : 拡散係数, $d:$ Stokes 半 径, $k$ : Boltzmann 定数, $\eta_{0}$ : 粘度) から, 著者らの実験

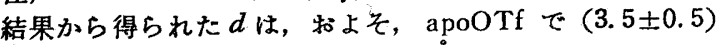
$\AA$, OTf $\cdot \mathrm{Tb}(\mathrm{III})_{2}$ で $(3.3 \pm 0.3) \AA$ であった.

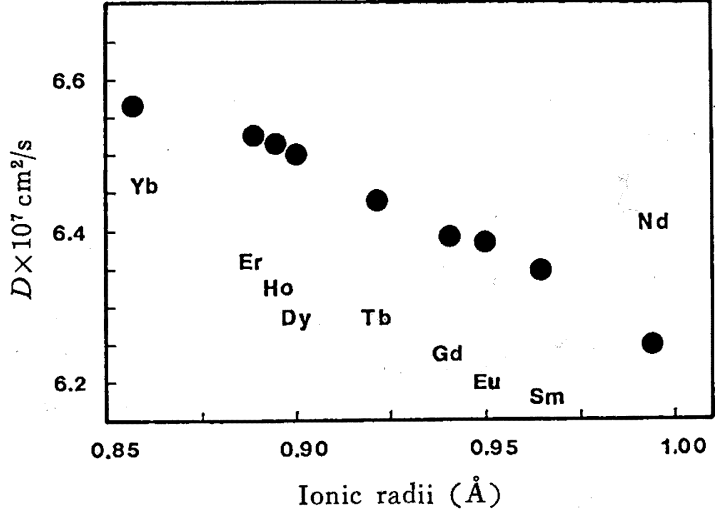

Fig. 3 Relationship between the diffusion coefficients of $\operatorname{Ln}($ III) saturated OTf complexes and the ionic radii of $\mathrm{Ln}$ (III)

The values of ionic radii of $\operatorname{Ln}($ III) were based on the data of Ref. 22

た。このことは，金属結合にともなら形態の変化が， N， C 結合 サイトに対し金属イオンが結合した時に生成する錯体生成量に何 らかの関連があるものと予想される。そこで, 金属イオンを OTf に添加したときに生成する，N扣よび Cサイト金属錯体生成量の 
割合を，EDTA 引き抜き法811011)17)によって計算し， D值の変化 と比較した。図 4 に，各飽和度における、Nサイト，Cサイト鍇 体の生成量の割合と $D$ 値の変化の割合を示した。これらの変化を 比較するために，それぞれの変化量を 1 に規格化した。また，図 中の実線と破線は 2.4 で述べたモデルにしたがって計算された $\mathrm{N}$ サイト，Cサイト錯体の生成量の割合を示している。本実験で 使用した試料の $\mathrm{N}$ サイト，Cサイト錯体の錯体生成量は，文献值 （2.4 参照）とよく一致し， N， C 結合サイト間に，金属結合にと もなら協同性は認められないことを確認した。したがって，N， C 結合サイトは，互いに独立に形態変化を起こしていると考劣られ る。本実験で得られた $D$ 值の変化は， Nサイト錯体の生成量より むCサイト錯体の生成量により近い挙動を示した。

そこで，Cサイト選択性である $\operatorname{Ln}($ III)イオンの添加による錯 体の $D$ 值の变化をより明確にするために，次節でNサイト選択性 を示す $\mathrm{Cu}(\mathrm{III})$ 錯体の錯形成による $D$ 值の変化について述べる。

\section{$3.4 \mathrm{Cu}(\mathrm{II}) \cdot 0 \mathrm{Tf}$ 金属錯体の㹡散係数}

园 5 (A) K OTf の $\mathrm{Cu}(\mathrm{II})$ イオンによる滴定曲線を示した。 $\operatorname{Ln}(\mathrm{III})$ と同様に OTf の 2 倍の点で飽和していることが確認さ れた。しかしながら， $\mathrm{Cu}$ (II) を結合させた場合の $D$ 值の変化は， $\operatorname{Ln}$ (III) の場合と異なり，図 5 (B) に示すようにS字様になっ た。 $\operatorname{OTf}(\mathrm{N}) \cdot \mathrm{Cu}(\mathrm{II})$ 錯体の場合は逆に, $[\mathrm{Cu}(\mathrm{II})] /[\mathrm{OTf}] \sim 1.2$ まで緩やかな勾配をるつ上昇曲線を示し，この比以上䭒和するま では大きな值の変化を示した。そして, $\mathrm{Cu}(\mathrm{II})$ イオンが飽和した 後は一定值を示した。この様に $N$ サイト選択性を示す金属イオン の場合は，Cサイト選択性のるのと異なる $D$ 值の变化を示した。 このことから，D値の変化は， N， C 結合サイトの金属結合にと

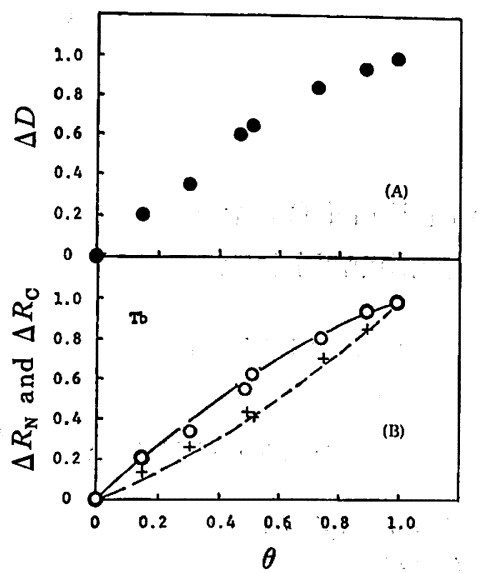

Fig. 4 (A) The increment of the $D$ value (O) for the $\mathrm{Tb}$ (III)-OTf complex with reference to apoOTf $\left(\Delta D=\left(D_{\text {obs }}-D_{\text {apo }}\right) /\left(D_{\text {sat }}-D_{\text {apo }}\right)\right)$ and (B) N- $\left(\Delta R_{\mathrm{N}}\right)$ and C-site occupancies $\left(\Delta R_{\mathrm{C}}\right)$ as a function of the saturation degree $(\theta)$ of bound $\mathrm{Tb}$

The solid and dotted lines refer respectively to the calculated $\mathrm{N}$ - and $\mathrm{C}$-site occupancies giving by Eq. 6, whereas + and $O$ refer to those determined by measuring the time course for the metal release by EDTA; $\Delta R_{\mathrm{N}}=[\mathrm{N}] /[\mathrm{N}]_{\mathrm{sat}}$, and $\Delta R_{\mathrm{C}}=[\mathrm{C}] /$ $[\mathrm{C}]_{\mathrm{Bat}}$

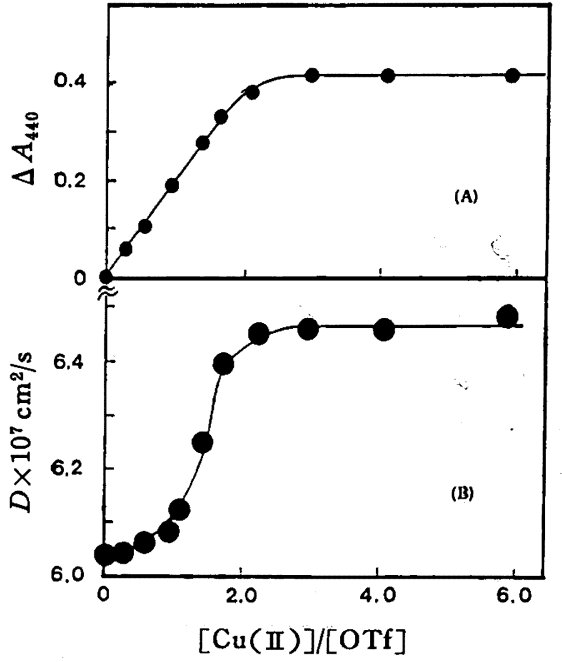

Fig. 5 Absorbance at $440 \mathrm{~nm}$ (A) and diffusion coefficient (B) of $\mathrm{Cu}$ (II)-OTf complex as a function of the molar ratio of $\mathrm{Cu}$ (II) ion to OTf

Conditions: $[\mathrm{OTf}]_{\mathrm{T}}=1.1 \times 10^{-4} \mathrm{~mol} \cdot \mathrm{dm}^{-8}$ (A), 4.5 $\times 10^{-5} \mathrm{~mol} \cdot \mathrm{dm}^{-8}$ (B) in $10 \mathrm{mmol} \cdot \mathrm{dm}^{-3}$ Tris- $\mathrm{HCl}$ buffer containing $10 \mathrm{mmol} \cdot \mathrm{dm}^{-8} \mathrm{NaHCO}_{3}, \mathrm{pH} \mathrm{8}$; Temp $25 \pm 0.2^{\circ} \mathrm{C}$

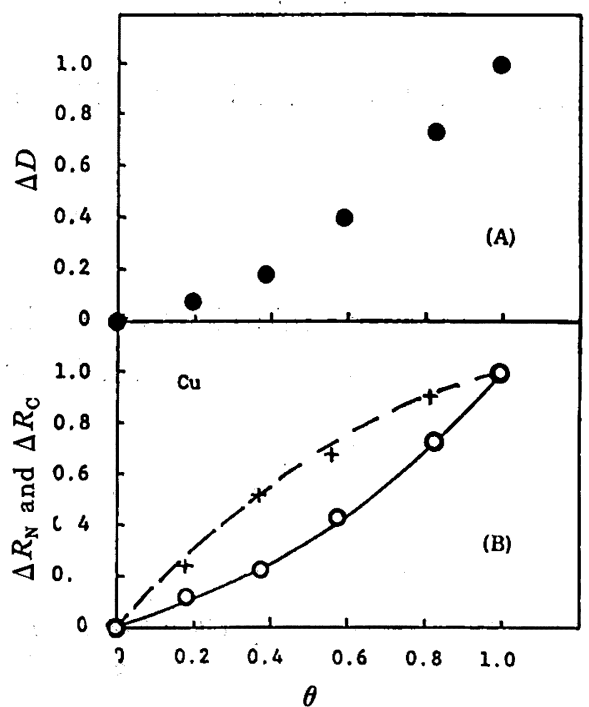

Fig. 6 (A) The increment of the $D$ value (O) for the $\operatorname{OTf}(\mathrm{N})-\mathrm{Cu}(\mathrm{II})$ complex with reference to a poOTf $\left(\Delta D=\left(D_{\text {obs }}-D_{\text {apo }}\right) /\left(D_{\text {sat }}-D_{\text {apo }}\right)\right)$ and (B) $\mathrm{N}-\left(\Delta R_{\mathrm{N}}\right)$ and $\mathrm{C}$-site occupancies $\left(\Delta R_{\mathrm{C}}\right)$ as a function of the saturation degree $(\theta)$ of bound $\mathrm{Cu}$ under the condition of $\mathrm{pH} 8$

The solid and dotted lines refer to the calculated $\mathrm{N}$ - and $\mathrm{C}$-site occupancies giving by Eq.6, whereas + and $O$ refer to those determined by mesuring the time course for the metal release by EDTA; $\Delta R_{\mathrm{N}}=[\mathrm{N}] /[\mathrm{N}]_{\mathrm{sats}}$ and $\Delta R_{\mathrm{C}}=[\mathrm{C}] /[\mathrm{C}]_{\mathrm{Bat}}$ 


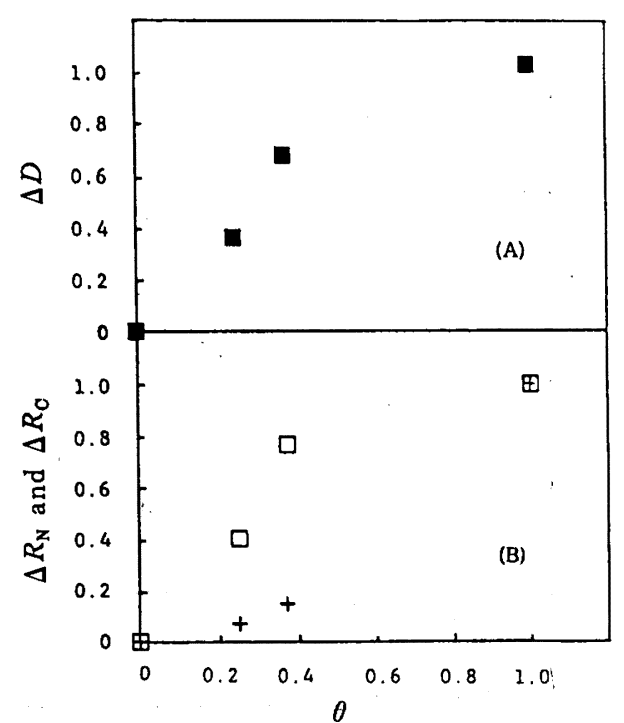

Fig. 7. (A) The increment of the $D$ value $(\square$ ) for the $\operatorname{OTf}(\mathrm{C})-\mathrm{Cu}$ (II) complex with reference to apoOTf $\left(\Delta D=\left(D_{\text {obs }}-D_{\text {apo }}\right) /\left(D_{\text {sat }}-D_{\text {apo }}\right)\right)$ and (B) N-site occupancies $\left(\Delta R_{\mathrm{N}}\right)$ and C-site occupancies $\left(\Delta R_{\mathrm{C}}\right)$ as a function of the saturation degree $(\theta)$ of bound $\mathrm{Cu}$

$\operatorname{OTf}(\mathrm{C})-\mathrm{Cu}$ (II) complex was prepared according to Ref. 16

+ and $\square$ refer to the calculated $\mathrm{N}$ - and $\mathrm{C}$-site occupancies determined by measuring the time cource for the metal release by $\operatorname{EDTA} ; \Delta R_{\mathrm{N}}=[\mathrm{N}] /$ $[\mathrm{N}]_{\mathrm{sat}}$, and $\Delta R_{\mathrm{C}}=[\mathrm{C}] /[\mathrm{C}]_{\mathrm{gat}}$

あなら選択性の違いによるすのと推測できた。困 4 と同様に，各
飽和度における $\operatorname{OTf}(\mathrm{N}) \cdot \mathrm{Cu}(\mathrm{II})$ 金属鍇体の $D$ 值の変化を比校 すると，Cサイト錯体生成量により近い变化をしていることが示 された（図6参照)。OTfに $\mathrm{Cu}$ (II) が結合するときる $\mathrm{N}, \mathrm{C}$ 金 属結合サイト間に協同性が認められないこと息を考兄合わせる と，金属イオンがNサイトに結合した時に起こるNドメインの形 態変化よりも，Cサイトに結合した場合に起こるCドメインの形 態変化の方が，より大きいものと推察される。

さらに,この点を明確にするために OTf(C)・Cu(II)錯体を調 製し，その錯体の $D$ 值を測定した（図 7 (A))。まず, 調製した $\operatorname{OTf}(\mathrm{C}) \cdot \mathrm{Cu}(\mathrm{II})$ 錯体の， N，C 結合サイト生成量を EDTA に よる $\mathrm{Cu}$ イオンの引き抜き法により決定した（図 7 (B))。明ら かにC結合サイトに，より多く結合していることを確認した。こ の時の $\operatorname{OTf}(\mathrm{C}) \cdot \mathrm{Cu}(\mathrm{II})$ 錯体の $D$ 値を測定すると，その変化の割

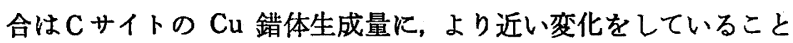
が示された。 $\operatorname{OTf}(\mathrm{C}) \cdot \mathrm{Cu}(\mathrm{II})$ と $\mathrm{OTf}(\mathrm{N}) \cdot \mathrm{Ca}(\mathrm{II})$ の $D$ 值を比 較してみると，たと文飽和度 $\theta$ が同じです（例えば図 6 打よび 7 の $\theta=0.4) ， \mathrm{C}$ サイト $\mathrm{Cu}$ 錯体の生成量が違らとD值も異なるこ とが示された。このようなことから，D值の変化はCサイト錯体 の生成とより密接な関係があるといらことが示唆された。

\section{4 結 語}

1) OTf 飞 Fe が結合すると, 分子の回転半径が小さくなるこ とが示されていたが ${ }^{12113)}, \operatorname{Ln}(\mathrm{III})$ 錯体の場合, 分子の収樎は, 結 合する金属のイオン半径に関連すること，また，この分子の収縮 と錯体の安定性の間によい相関性が認められた。

2）金属イオンの結合により，起こる分子の収縮は，N結合サイ ト錯体よりC結合サイト錯体の方が大きいこと、そして OTf の N，Cサイト選択性に関係ないことがわかった。

\title{
Dynamic Light Scattering Study of the Conformational Change of Ovotransferrin Induced by the Binding of Lanthanoid lons
}

Noriyuki Sasaki, Hisashi Honda, Hirofumi Yajima, Hiroyuki Momomi, Kaoru Ichimura, Kazuo SATAKE** and Ryuichi ENDo*

\author{
Department of Applied Chemistry, Faculty of Science, Science University of Tokyo; \\ Kagurazaka, Shinjuku-ku, Tokyo 162 Japan \\ ** Department of Chemistry, Faculty of Science, Science University of Tokyo ; \\ Kagurazaka, Shinjuku-ku, Tokyo 162 Japan
}

In order to elucidate the predominant factors for the conformational change of chicken ovotransferrin (OTf), which has one metal-binding site in each of amino (N) and carboxyl (C) terminal domains, induced by metal binding, the effects of the coordinated metal ions on the diffusion coefficients $(D)$ of the metal-OTf complexes were investigated by means of dynamic light scattering technique using various lanthanoid $\left(\mathrm{Ln}^{3+}\right)$ ions with a high affinity for C metal-binding site. The $D$ values of the OTf complexes increased with increasing amounts of bound $\mathrm{Ln}^{3+}$ up to $\left(\mathrm{Ln}^{3+}\right) /(\mathrm{OTf})(=R) \simeq 1.2$, and then gradually changed, leveling off above $R \simeq 2$, regardless of the species of $\mathrm{Ln}^{3+}$ metals. The behavior of $D$ values with increasing degree of saturation of bound metals was related to that of the C-site complexes compared to the $\mathrm{N}$-site complexes. In addition, the $D$ values of the saturated OTf complexes increased with decreasing ionic radii of $\mathrm{Ln}^{3+}$. These results suggested that the stokes radii 
of the OTf complexes appreciably depend on the ionic radii of bound $\mathrm{Ln}^{3+}$ and that the contraction of the OTf molecules originates from a predominant metal binding to the $\mathrm{C}$-site compared to the $\mathrm{N}$-site. 